\title{
PENGARUH PENGETAHUAN DAN KOMPATIBILITAS TERHADAP MINAT BERINVESTASI DI PASAR MODAL PADA MAHASISWA POLITEKNIK NEGERI BATAM
}

\author{
Fiona Bintang Thara $^{1)}$, Muhammad Ramadhan Slamet, S.E., M.Acc. ${ }^{2}$ * \\ ${ }^{1}$ Jurusan Manajemen Bisnis, Politeknik Negeri Batam \\ email: fionahasugian@gmail.com \\ 2 Jurusan Manajemen Bisnis, Politeknik Negeri Batam \\ email: ramadhanslamet@ polibatam.ac.id
}

\begin{abstract}
This research aims to know the effect of investment motivation on investment interest in the capital market in students, the effect of investment knowledge on investment interest in the capital market, and the effect of investment motivation, and investment knowledge on investment interest in capital markets in students. Participants in this study were students studying at Politeknik Negeri Batam majoring in Managerial Accounting and Business Administration semesters 5 and 7. The research sample was taken using purposive sampling method with 213 respondents as samples. Data collection was done by distributing questionnaires to Politeknik Negeri Batam students. The criteria used in this study were students of 2015 and 2016 who were pursuing and taking courses in Business Finance and Capital Market and Risk Management. Instrument testing was analyzed using validity test and reliability test. Data analysis techniques used in this study is multiple linear regression analysis. The results of the analysis show that there is an influence of knowledge and compatibility with interest in investing in the capital market.
\end{abstract}

Keywords: investment knowledge, compatibility, investment interest in capital markets.

\begin{abstract}
ABSTRAK
Penelitian ini bertujuan untuk mengetahui pengaruh pengetahuan dan kompatibilitas terhadap minat berinvestasi di pasar modal pada mahasiswa Politeknik Negeri Batam. Pengumpulan data dilakukan dengan menyebarkan kuesioner ke mahasiswa Politeknik Negeri Batam jurusan Akuntansi Manajerial dan Administrasi Bisnis semester 5 dan 7. Penarikan sampel penelitian menggunakan metode purposive sampling, dan sampel yang digunakan sebanyak 213 responden. Kriteria yang digunakan dalam penelitian ini adalah mahasiswa angkatan 2015 dan 2016 yang sedang menempuh dan telah menempuh mata kuliah Keuangan Bisnis dan Pasar Modal dan Manajemen Resiko. Instrumen penelitian ini dianalisis dengan menggunakan uji validitas dan uji reliabilitas. Teknik analisis data yang digunakan dalam penelitian ini adalah analisis regresi linier berganda. Hasil penelitian ini menunjukkan adanya pengaruh pengetahuan dan kompatibilitas terhadap minat investasi di pasar modal.
\end{abstract}

Kata Kunci: pengetahuan investasi, kompatibilitas, minat investasi di pasar modal. 


\section{PENDAhUlan}

Investasi di pasar modal merupakan salah satu alternatif investasi yang mudah diakses oleh masyarakat luas semenjak Bursa Efek Indonesia (BEI) didirikan. Namun, aktivitas investasi ini masih merupakan hal yang relatif baru bagi masyarakat Indonesia. Jika dibandingkan negara lain, animo masyarakat Indonesia untuk berinvestasi masih cukup rendah. Rendahnya animo masyarakat ini salah satunya disebabkan oleh pengetahuan yang minim mengenai investasi di pasar modal. Berdasarkan Investor Daily Indonesia (2011) investor Indonesia hanya $0,15 \%$ dari jumlah penduduknya. Perbandingan antara jumlah investor dan penduduk tersebut berbeda jauh dengan sejumlah negara seperti Malaysia (15\%), Singapura (30\%), dan Australia (25\%).

Salah satu institusi pendidikan yang menyelenggarakan Galeri Investasi Bursa Efek Indonesia adalah Politeknik Negeri Batam. Ternyata jumlah investor saham Politeknik Negeri Batam khususnya mahasiswa masih sangat rendah. Dari data yang sudah diambil dari Pojok Bursa di Politeknik Negeri Batam, dari total jumlah mahasiswa yang Aktif sebanyak 4.488 mahasiswa, hanya ada 64 mahasiswa saja yang aktif dalam berinvestasi sehingga bisa disimpulkan bahwa hanya 1,43\% investor mahasiswa yang aktif dalam berinvestasi.

Pengetahuan adalah salah satu alasan yang berpengaruh dalam berinvestasi. Pengetahuan investasi adalah pengetahuan dasar yang dimiliki untuk melakukan investasi. Hal ini bertujuan agar investor terhindar dari praktikpraktik investasi yang tidak rasional (judi), budaya ikut-ikutan, penipuan, dan resiko kerugian. Menurut Halim (2005), Diperlukan pengetahuan yang cukup, pengalaman serta naluri bisnis untuk menganalisis efek-efek mana yang akan dibeli dalam melakukan investasi di pasar modal. Pengetahuan yang memadai akan cara berinvestasi yang benar amat diperlukan guna menghindari terjadinya kerugian saat berinvestasi di pasar modal, seperti pada instrumen investasi saham.

Faktor lain yang dapat memengaruhi seseorang dalam berinvestasi saham di pasar modal adalah kompatibilitas. Definisi kompatibilitas sendiri berarti sejauh mana suatu inovasi dianggap lebih mampu bekerja dan bergerak sesuai dengan sistem konsumen yang ada nilai, pengalaman, dan kebutuhan. Rogers (1995) mendefinisikan kompatibilitas sebagai tingkat konsistensi antara teknologi dan kebutuhan pelanggan, rutinitas kehidupan sehari-hari, pengalaman dan nilai- nilai. Penelitian yang dilakukan penulis merupakan pengembangan dari peneltian yang telah dilakukan oleh Pajar (2017), pada mahasiswa fakultas ekonomi Universitas Negeri Yogyakarta pada tahun 2017. Penelitian sebelumnya yang dilakukan oleh Pajar (2017) ingin membuktikan apakah motivasi dan pengetahuan berpengaruh terhadap minat investasi di pasar modal. Penelitian tersebut semakin menarik untuk dibahas karena penelitian Pajar (2017) mengatakan bahwa minat investasi mahasiwa cukup tinggi terutama saat di awal pembelajaran, namun tidak sedikit dari mahasiswa yang mengurungkan niatnya ketika teori yang dipelajari dibangku kuliah diperaktikan di dunia nyata. Perbedaan penelitian ini dengan penelitian Pajar (2017) adalah pertama Tempat, waktu, dan sampel penelitian. Kedua Penelitian ini mengganti variabel motivasi dengan variabel kompatibilitas. Ketiga adanya penentuan kriteria dalam penerimaan responden penelitian, dimana pada penelitian ini mengambil mahasiswa Politeknik Negeri Batam, yang mahasiswanya adalah jurusan Akuntansi Manajerial dan Administrasi Bisnis.

Tujuan dari penelitian ini untuk mengetahui pengaruh pengetahuan dan kompatibilitas terhadap minat investasi di pasar modal pada mahasiswa Politeknik Negeri Batam.

\section{KAJIAN LITERATUR DAN PENGEMBANGAN HIPOTESIS}

\section{Teori Tindakan Beralasan (Theory of Reason Action)}

Theory of Reasoned Action (TRA) atau Teori Tindakan Beralasan atau Teori Aksi Beralasan mengatakan bahwa sikap mempengaruhi perilaku melalui suatu proses pengambilan keputusan yang teliti dan 
beralasan, dan dampaknya terbatas hanya pada tiga hal. Pertama, perilaku tidak banyak ditentukan oleh sikap umum tetapi oleh sikap yang spesifik terhadap sesuatu. Kedua, perilaku tidak hanya dipengaruhi oleh sikap tetapi juga oleh norma subyektif (subjective norms) yaitu keyakinan kita mengenai apa yang orang lain inginkan agar kita lakukan. Ketiga, sikap terhadap suatu perilaku bersamasama norma subyektif membentuk suatu intensi atau niat untuk berperilaku tertentu. Jogiyanto (2007) berpendapat bahwa intensi atau niat merupakan fungsi dari sua determinan dasar, yaitu sikap individu terhadap perilaku (merupakan aspek personal) dan persepsi individu terhadap tekanan sosial untuk melakukan atau untuk tidak melakukan perilaku yang disebut dengan norma subyektif. Secara singkat, praktik atau perilaku menurut Theory of Reasoned Action (TRA) dipengaruhi oleh niat, sedangkan niat dipengaruhi oleh sikap dan norma subyektif.

\section{Teori Perilaku Terencana (Theory of Planned Behavior)}

Teori Perilaku Terencana atau TPB (Theory of Planned Behavior) merupakan pengembangan lebih lanjut dari Teori Perilaku Beralasan (Theory of Reasoned Action). Theory of Planned Behavior merupakan kerangka berpikir konseptual yang bertujuan untuk menjelaskan determinan perilaku tertentu. Menurut Ajzen (1985), faktor sentral dari perilaku individu adalah bahwa perilaku itu dipengaruhi oleh niat individu (behavior intention) terhadap perilaku tertentu tersebut. Niat untuk berperilaku dipengaruhi oleh tiga komponen yaitu (1) sikap (attitude), (2) norma subjektif (subjective norm) dan (3) persepsi kontrol keperilakuan (perceived behavior control). Seseorang dapat saja memiliki berbagai macam keyakinan terhadap suatu perilaku, namun ketika dihadapkan pada suatu kejadian tertentu, hanya sedikit dari keyakinan tersebut yang timbul untuk mempengaruhi perilaku. Sedikit keyakinan inilah yang menonjol dalam mempengaruhi perilaku individu (Ajzen 1991).

\section{Teori Heuristik (Heuristic Theory)}

Heuristik didefinisikan sebagai strategi pengambilan keputusan yang cepat dan kadang tidak menggunakan banyak informasi karena pengambil keputusan menganggap sebagai suatu kebiasaan. Terdapat dua jenis heuristik yaitu heuristik tipe pertama adalah pengambilan keputusan dengan cepat karena tidak terlalu penting, misalnya lebih memilih burger dibanding hot dog karena biasanya begitu. Heuristik tipe kedua adalah jika pengambilan keputusan yang diambil lebih membutuhkan upaya, misalnya "sekarang lebih memilih hot dog karena disajikan dengan cara berbeda dan saya suka mencoba sesuatu yang baru." Kahneman dan Tversky tampaknya menjadi salah satu penulis pertama yang mempelajari tiga faktor yang diperkenalkan oleh heuristik yaitu keterwakilan, ketersediaan bias, dan penahan (Kahneman \& Tversky, 1974). Waweru et al (2008) juga membuat daftar dua faktor yang bernama kekeliruan penjudi dan kelebihan teori heuristik.

Banyak penelitian menunjukkan bahwa trading secara berlebihan adalah salah satu efek dari investor. Bukti yang menunjukkan bahwa analisis keuangan merevisi penilaian mereka tentang perusahaan secara perlahan-lahan, bahkan ketika ada indikasi yang kuat yang membuktikan bahwa penilaian tidak lagi benar. Investor dan analis yang sering terlalu percaya diri di daerah yang mereka ketahui (Evans, 2006). Kepercayaan diri yang berlebihan diyakini untuk meningkatkan ketekunan dan penentuan, fasilitas mental, dan toleransi risiko. Kepercayaan diri yang berlebihan dapat membantu untuk mempromosikan kinerja profesional. Perlu juga dicatat bahwa kepercayaan diri yang berlebihan dapat meningkatkan persepsi lain dari kemampuan seseorang, yang dapat membantu untuk mencapai promosi dan durasi investasi yang lebih besar dengan lebih cepat. Ketersediaan bias terjadi ketika orang menggunakan informasi yang mudah didapat secara berlebihan. Pada perdagangan saham, bias ini memanifestasikan dirinya melalui preferensi investasi perusahaan-perusahaan lokal yang investor pahami atau informasi yang mudah didapatkan, meskipun ini merupakan prinsipprinsip diversifikasi, disebut juga sebagai manajemen portofolio untuk optimasi (Waweru et al., 2003). 


\section{Pengembangan Hipotesis}

Pengaruh pengetahuan terhadap minat berinvestasi di pasar modal, Dilihat dari Teori Tindakan Beralasan (Theory of Reasoned Action) yang menjelaskan bahwa teori tersebut dipengaruhi oleh niat, sedangkan niat dipengaruhi oleh sikap dan norma subyektif. Hal ini menunjukkan bahwa niat berperilaku dapat menunjukkan perilaku yang akan dilakukan oleh seseorang. Hasil penelitian Merawati (2015) menunjukkan adanya pengaruh yang signifikan dari pengetahuan investasi terhadap minat investasi mahasiswa. Hasil ini menunjukkan bahwa materi yang diberikan pada mata kuliah manajemen investasi mampu memberikan pemahaman dasar terkait jenis investasi, return, risiko yang harus dipertimbangkan oleh mahasiswa sebagai calon investor. Oleh karena itu, hipotesis dirumuskan sebagai berikut.

$\mathrm{H}_{1}$ : Pengetahuan investasi berpengaruh positif signifikan pada minat berinvestasi

Pengaruh kompatibilitas terhadap minat berinvestasi

Hasil penelitian dari Njuguna (2017) mengungkapkan bahwa adanya pengaruh kompatibilitas terhadap minat investasi. Kompatibilitas memiliki hubungan yang positif dengan keinginan setiap orang untuk berinvestasi. Hasil ini menunjukkan bahwa kompatibilitas atau gaya hidup mampu mempengaruhi dan menjadi bahan pertimbangan seseorang untuk berinvestasi. Oleh karena itu, hipotesis dirumuskan sebagai berikut.

$\mathrm{H}_{2}$ : Kompatibilitas berpengaruh positif signifikan pada minat berinvestasi

Berdasarkan pengembangan hipotesis yang telah disajikan di atas, model penelitian ini dapat dilihat pada gambar 1.

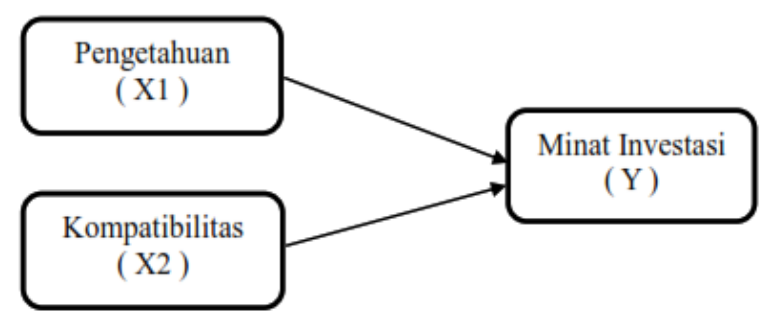

\section{METODE DAN PENELITIAN}

Jenis dan Sumber Data

Jenis data yang digunakan dalam penelitian ini terdiri dari data kuantitatif yaitu data berupa angka- angka yang berasal dari laporan keuangan perusahaan yang menjadi sampel penelitian. Dilihat dari sumber datanya, penelitian ini menggunakan data primer, yaitu data kuesioner yang dikumpulkan dari responden.

\section{Definisi Operasional Variabel dan Pengukuran}

Variabel Dependen

Adapun variabel independen dalam penelitian ini adalah minat berinvestasi. Minat berinvestasi adalah keinginan untuk mencari tahu tentang jenis suatu investasi, mau meluangkan waktu untuk mempelajari lebih jauh tentang investasi dengan mengikuti pelatihan dan seminar investasi, serta mencoba berinvestasi (Kusumawati, 2011). Ukuran indikator yang digunakan untuk minat investasi adaah keinginan untuk menncari tahu tentang jenis suatu investasi, mau meluangkan waktu untuk mempelajari lebih jauh tentang investasi, serta mencoba berinvestasi. Variabel minat investasi diukur dengan mengajukan kuesioner berskala likert 5 poin.

Variabel Independen

Adapun variabel independen dalam penelitian ini adalah.

1. Pengetahuan investasi

Pengetahuan investasi adalah pengetahuan dasar yang dimiliki untuk melakukan investasi. Pengetahuan yang memadai akan cara berinvestasi yang benar sangat diperlukan guna menghindari terjadinya kerugian saat berinvestasi di pasar modal, seperti pada instrumen investasi saham. Ukuran indikator yang digunakan untuk pengetahuan investasi adalah pemahaman tentang kondisi berinvestasi, pengetahuan dasar penilaian saham, tingkat risiko dan tingkat pengembalian (return) investasi. Variabel

Gambar 1. Kerangka pemikiran 
ini diukur dengan mengajukan kuesioner berskala likert 5 poin.

2. Kompatibilitas

Kompatibilitas sebagai tingkat konsistensi antara teknologi dan kebutuhan pelanggan baru, rutinitas kehidupan sehari-hari, pengalaman dan nilai- nilai. Kompatibilitas juga berhubungan dengan gaya hidup individu dan teknologi. Ukuran indikator yang digunakan untuk kompatibilitas adalah gaya hidup, kebutuhan, dan nilai. Variabel ini diukur dengan mengajukan kuesioner berskala likert 5 poin.

\section{Teknik Penarikan Sampel}

Teknik penarikan sampel yang digunakan dalam penelitia ini adalah purposive sampling, yaitu teknik pengambilan sampel berdasarkan kriteria. Dalam penelitian ini, kriteria yang diajukan peneliti sebagai sampel adalah mahasiswa yang telah menempuh mata kuliah Keuangan Bisnis pada jurusan Administrasi Bisnis dan mata kuliah Pasar Modal dan Manajemen Resiko pada jurusan Akuntansi Manajerial Politeknik Negeri Batam. Mahasiswa jurusan Administrasi Bisnis Politeknik Negeri Batam yang sedang belajar dan sudah belajar mata kuliah Keuangan Bisnis adalah mahasiswa yang sedang duduk di semester 5 dan semester 7. Sementara, mahasiswa jurusan Akuntansi Manajerial Politeknik Negeri Batam yang sedang belajar Pasar Modal dan Manajemen Resiko adalah mahasiswa yang sedang duduk di semester 7 .

Tabel 1. Sampel

\begin{tabular}{|c|c|c|c|c|c|}
\hline \multicolumn{3}{|c|}{ Administasi Bisnis } & \multicolumn{3}{|c|}{ Akuntasi Manajerial } \\
\hline Semester & Kelas & Jumlah & Semester & Kelas & Jumlah \\
\hline 5 & Reguler Pagi $\mathrm{A}$ & 30 & 7 & Reguler Pagi B & 30 \\
\hline 5 & Reguler Pagi B & 28 & 7 & Reguler Malam & 30 \\
\hline 5 & Reguler Malam & 30 & & & \\
\hline 7 & Reguler Pagi A & 27 & & & \\
\hline 7 & Reguler Malam & 38 & & & \\
\hline \multicolumn{2}{|c|}{ Jumlah Adminstrasi Bisnis } & 153 & \multicolumn{2}{|c|}{ Jumlah Akuntansi Manajerial } & 60 \\
\hline \multicolumn{5}{|c|}{ Jumlah Keseluruhan } & 213 \\
\hline
\end{tabular}

\section{Teknik Pengolahan Data}

Teknik pengolahan data yang digunakan dalam penelitian ini yaitu melakukan tabulasi data. Responden dari kuesioner yang dibutuhkan untuk perhitungan variabel dipindahkan dari laporan keuangan ke dalam program Microsoft Office Excel. Datadata yang dipindahkan dari responden kuesioner untuk melakukan tabulasi data yaitu jawaban dari setiap pertanyaan kuesioner dengan skala yang sudah ditentukan yaitu skala likert 5 poin. Data ini kemudian diolah dengan bantuan alat pengolahan data yaitu IBM SPSS 22.

\section{Teknik Analisis Data}

\section{Uji Validitas}

Uji validitas digunakan untuk mengukur sah atau valid tidaknya suatu kuesioner. Suatu kuesioner dikatakan valid jika pertanyaan pada kuesioner mampu untuk mengungkapkan sesuatu yang akan diukur oleh kuesioner tersebut. Uji validitas ingin mengukur apakah pertanyaan dalam kuesioner yang sudah kita buat betul-betul dapat mengukur apa yang hendak kita ukur.

\section{Uji Reliabilitas}

Realibilitas sebenarnya adalah alat untuk mengukur suatu kuesioner yang merupakan indikator dari variabel atau konstruk. Suatu kuesionoer dikatakan reliable atau handal jika jawaban seseorang terhadap pernyataan adalah konsisten atau stabil dari waktu ke waktu.

\section{Uji Asumsi Klasik}

Uji asumsi klasik yang perlu dilakukan harus disesuaikan dengan jenis pengujian yang dibutuhkan untuk penelitian yang bersangkutan. Penelitian ini melakukan uji normalitas, heteroskedastisitas dan multikolinearitas.

Analisis Regresi

Analisis regresi linear sederhana digunakan untuk menguji pengaruh variabel independen terhadap variabel dependen (Ghozali, 2013). Model regresi yang digunakan dalam penelitian ini adalah:

$$
\mathrm{Y}=\mathbf{a}+\mathbf{b} 1 \mathrm{X} 1+\mathbf{b} 2 \mathrm{X} 2+\mathbf{e}
$$

Keterangan:

$\mathrm{Y}=$ Minat Investasi Mahasiswa

$\mathrm{a}=$ Konstansta

b1= Koefisien regresi untuk X1 
b2 $=$ Koefisien regresi untuk X2

$\mathrm{X} 1=$ Pengetahuan investasi

$\mathrm{X} 2=$ Kompatibilitas

e = Nilai Residu

\section{HASIL DAN PEMBAHASAN}

\section{Statistik Deskriptif}

Hasil statistik deskriptif sampel yang digunakan dalam penelitian ini dapat dilihat pada tabel 2 .

\section{Tabel 2 Statistik Deskriptif}

\begin{tabular}{|c|c|c|c|c|c|}
\hline & \multicolumn{5}{|c|}{ Descriptive Statistic } \\
\hline & $\mathrm{N}$ & Minimum & Maximum & Mean & $\begin{array}{l}\text { Std. } \\
\text { Deviat } \\
\text { ion }\end{array}$ \\
\hline PENGETAHUAN & 213 & 33 & 55 & 44.99 & 4.752 \\
\hline KOMPATIBILITAS & 213 & 6 & 30 & 21.40 & 5.324 \\
\hline
\end{tabular}

Sumber: Hasil Olahan IBM SPSS 22

Berdasarkan tabel 2, jumlah sampel akhir yang digunakan dalam penelitian berjumlah 213, dari 213 sampel ini nilai variabel pengetahuan yang terkecil sebesar 33, dan pengetahuan terbesar adalah 55. Rata-rata variabel pengetahuan sebesar 44,99 dengan standar deviasi sebesar 4,752. Nilai terkecil dari variabel kompatibilitas adalah 6, sedangkan nilai terbesarnya adalaha 30. Dari 213 sampel, rata-rata dari variabel kompatibilitas adalah 21,40 dengan standar deviasi sebesar 5,324.

\section{Uji Validitas}

Berikut hasil uji validitas untuk variabel pengetahuan investasi.

\section{Tabel 3 Hasil Uji Validitas Variabel Pengetahuan Investasi}

\begin{tabular}{|c|c|c|c|}
\hline No & Korelasi & R Tabel & Keterangan \\
\hline 1. & 0,494 & 0,1338 & Valid \\
\hline 2. & 0,523 & 0,1338 & Valid \\
\hline 3. & 0,563 & 0,1338 & Valid \\
\hline 4 & 0,532 & 0,1338 & Valid \\
\hline 5. & 0,576 & 0,1338 & Valid \\
\hline 6. & 0,551 & 0,1338 & Valid \\
\hline 7. & 0,424 & 0,1338 & Valid \\
\hline 8. & 0,548 & 0,1338 & Valid \\
\hline 9. & 0,596 & 0,1338 & Valid \\
\hline 10. & 0,681 & 0,1338 & Valid \\
\hline 11. & 0,676 & 0,1338 & Valid \\
\hline
\end{tabular}

Sumber: Hasil Olahan IBM SPSS 22

Berikut validitas untuk variabel kompatibilitas.

\section{Tabel 4 Hasil Uji Validitas Variabel Kompatibilitas}

\begin{tabular}{|c|l|l|c|}
\hline No & Korelasi & R Tabel & Keterangan \\
\hline 1. & 0,859 & 0,1338 & Valid \\
\hline 2. & 0,921 & 0,1338 & Valid \\
\hline 3. & 0,925 & 0,1338 & Valid \\
\hline 4. & 0,902 & 0,1338 & Valid \\
\hline 5. & 0.831 & 0,1338 & Valid \\
\hline 6. & 0,883 & 0,1338 & Valid \\
\hline
\end{tabular}

Sumber: Hasil Olahan IBM SPSS 22

Berikut validitas untuk variabel minat berinvestasi.

\section{Tabel 5 Hasil Uji Validitas Variabel Minat} Berinvestasi

\begin{tabular}{|c|l|l|c|}
\hline No & Korelasi & R Tabel & Keterangan \\
\hline 1. & 0,580 & 0,1338 & Valid \\
\hline 2. & 0,645 & 0,1338 & Valid \\
\hline 3. & 0,580 & 0,1338 & Valid \\
\hline 4. & 0,631 & 0,1338 & Valid \\
\hline 5. & 0,675 & 0,1338 & Valid \\
\hline 6. & 0,665 & 0,1338 & Valid \\
\hline 7. & 0,642 & 0,1338 & Valid \\
\hline 8. & 0,736 & 0,1338 & Valid \\
\hline 9. & 0,700 & 0,1338 & Valid \\
\hline
\end{tabular}

Sumber: Hasil Olahan IBM SPSS 22

Dari tabel 3,4, dan 5 diperoleh bahwa tidak satupun indikator yang dinilai gugur dalam menjelaskan suatu variabel. Hal ini dapat diidentifikasi dari seluruh nilai $\mathrm{r}$ hitung pada setiap indikator lebih besar dari nilai $r$ tabel $\mathrm{df}$ $=\mathrm{N}=213$ yaitu 0,1338 .

Uji Reliabilitas

Pengujian reliabilitas dalam penelitian ini adalah dengan menggunakan rumus Alpha. Pengujian reliabilitas ini dilakukan menggunakan computer dengan bantuan program IBM SPSS 22. Dalam penelitian ini pengujian reliabilitas dilakukan terhadap 213 responden. 
Tabel 6 Hasil Uji Reliabilitas

\begin{tabular}{lll}
\hline \multicolumn{1}{c}{ Variabel } & Alpha & Keterangan \\
\hline Pengetahuan Investasi & 0,744 & Reliabel \\
\hline Kompatibilitas & 0,946 & Reliabel \\
\hline Minat Investasi & 0,828 & Reliabel \\
\hline \multicolumn{2}{l}{ Sumber: Hasil Olahan IBM SPSS 22} &
\end{tabular}

Dari tabel 6 diperoleh hasil yang menunjukkan bahwa semua variabel mempunyai koefisien alpha yang lebih besar dari 0,6 sehingga dapat dikatakan semua konsep pengukur variabel yang digunakan dalam penelitian ini adalah reliabel. Untuk selanjutnya indikator pada masing-masing variabel tersebut layak digunakan sebagai alat ukur dalam pengujian statistik.

\section{Uji Asumsi Klasik}

\section{Uji Normalitas}

Uji normalitas bertujuan untuk menguji apakah dalam model regresi, variabel pengganggu atau residual memiliki distribusi normal (Ghozali, 2013). Pengujian normalitas residual dapat menggunakan uji statistik nonparametrik Kolmogorov-Smirnov (K-S). Jika probabilitas signifikansi lebih besar dari 0,05 maka data residual berdistribusi normal. Hasil uji normalitas yang dilakukan pada sampel awal penelitian berjumlah 213 data dapat dilihat pada tabel 7 .

\section{Tabel 7 Hasil Uji Normalitas}

\begin{tabular}{lc}
\multicolumn{2}{c}{$\begin{array}{c}\text { Unstandardized } \\
\text { Residual }\end{array}$} \\
\hline $\mathrm{N}$ & 213 \\
\hline Test Statistic & .059 \\
\hline Asymp. Sig. (2-tailed) & .065 \\
\hline
\end{tabular}

Sumber: Hasil Olahan IBM SPSS 22

Pada tabel 7 hasi uji table128tic nonparametrik Kolmogorov-Smirnov (K-S) diketahui nilai signifikan $0,065>0,05$, maka dapat disimpulkan bahwa nilai residual berdistribusi normal.

\section{Uji Heteroskedastisitas}

Uji heteroskedastisitas bertujuan untuk menguji apakah dalam model regresi terjadi ketidaksamaan variance dari residual satu pengamatan ke pengamatan yang lain. Jika variance dari residual satu pengamatan ke pengamatan lain tetap, maka disebut homoskedastisitas dan jika berbeda disebut heteroskedastisitas. Model regresi yang baik adalah tidak terjadi heteroskedastisitas. Salah satu pengujian yang dapat digunakan untuk menganalisis apakah dalam suatu pengamatan terjadi heteroskedastisitas adalah uji glejser. Jika probabilitas signifikansi lebih besar dari 0,05, maka dikatakan tidak terjadi heteroskedastisitas Ghozali, (2013). Hasil pengujian heteroskedastisitas dapat dilihat pada table 8 .

\section{Tabel 8 Hasil Uji Heteroskedastisitas}

\begin{tabular}{llccc}
\hline \multicolumn{5}{c}{ Correlation } \\
\hline & Pengetahuan & Kompatibiltas & $\begin{array}{c}\text { Unstrandardized } \\
\text { ed. Residual }\end{array}$ \\
\hline Pengetahuan & Correlation Coefficient & 1.000 & .481 & -.022 \\
& Sig. (2-tailed) &. & .000 & .750 \\
& $\mathrm{~N}$ & 213 & 213 & 213 \\
\hline Kompatibilitas & Correlation Coefficient & .481 & 1.000 & -.032 \\
& Sig. (2-tailed) & .000 &. & .640 \\
& $\mathrm{~N}$ & 213 & 213 & 213 \\
\hline \multicolumn{5}{c}{ Sumber: Hasil Olahan IBM SPSS 22 }
\end{tabular}

Pada tabel 8 hasil uji heteroskedastisitas diketahui nilai signifikan variabel pengetahuan $0,750>0,05$, dan variabel kompatibilitas 0,640 $>0,05$ maka dapat disimpulkan bahwa tidak terjadi heteroskedastisitas.

\section{Uji Multikolinearitas}

Tujuan pengujian terhadap asumsi klasik multikolonieritas adalah untuk mengetahui apakah ada atau tidaknya korelasi antar variabel independent dalam model regresi. Uji multikolonieritas dapat dilakukan apabila terdapat lebih dari satu variabel independen dalam model regresi. Cara yang paling umum digunakan oleh para peneliti dalam melakukan pendeteksian ada atau tidaknya problem multikolonieritas pada model regresi adalah dengan melihat nilai Tolerance dan VIF (Variance Inflation Factor). Nilai yang direkomendasikan untuk menunjukan tidak adanya problem multikolonieritas adalah nilai Tolerance harus $>0.10$ dan nilai VIF $<10$ (Hair, 2013). Hasil uji multikolinearitas dapat dilihat pada tabel 9 . 
Tabel 9 Hasil Uji Multikolinearitas

\begin{tabular}{lcc}
\hline \multicolumn{2}{c}{ Coefficients* $^{2}$ Collinearity Statistics } \\
\cline { 2 - 3 } Model & \multicolumn{2}{c}{ Tolerance } \\
\hline 1. (Constant) & & \\
\hline Pengetahuan &, 762 & 1,312 \\
\hline Kompatibilitas &, 762 & 1,312 \\
\hline
\end{tabular}

Sumber: Hasil Olahan IBM SPSS 22

Berdasarkan tabel 9 diatas, dapat diketahui bahwa nilai tolerance $>0,1$ dan $\mathrm{VIF}<10$, dengan demikian model yang diajukan dalam penelitian tidak terjadi multikolinearitas.

Hasil Pengujian Hipotesis

Berikut hasil pengujian hipotesis.

Tabel 10 Hasil Pengujian Hipotesis

\begin{tabular}{ccc}
\hline Variabel & $\mathrm{T}$ & Sig. \\
\hline & & \\
\hline (Konstanta) & 3.386 & .001 \\
PENGETAHUAN & 7.489 & .000 \\
KOMPATIBILITAS & 4.639 & .000 \\
\hline
\end{tabular}

Sumber: Hasil Olahan IBM SPSS 22

Berdasarkan hasil output SPSS di atas kita dapat melihat dimana nilai $t$ hitung variabel pengetahuan lebih besar dari pada nilai t tabel $(7,489>0,1338)$ dengan tingkat signifikan dibawah 0,05 yaitu 0,000 . Oleh sebab itu, dapat disimpulkan bahwa pengetahuan berpengaruh positif signifikan terhadap minat berinvestasi.

Sementara itu, nilai $t$ hitung variabel pengetahuan lebih besar dari pada nilai t tabel $(4,639>0,1338)$ dengan tingkat signifikan dibawah 0,05 yaitu 0,000 . Oleh sebab itu, dapat disimpulkan bahwasannya kompatibilitas berpengaruh positif signifikan terhadap minat berinvestasi.

\section{PEMBAHASAN}

Pengaruh Pengetahuan Terhadap Minat Berinvestasi

Hasil dari penelitian ini menunjukkan bahwa variabel pengetahuan memengaruhi minat berinvestasi. Hal ini sesuai dengan penelitian Merawati (2015) yang menyatakan bahwa pengetahuan investasi memiliki efek positif pada minat mahasiswa untuk menanamkan modalnya di pasar modal. Penelitian Robb (2011) juga menunjukkan bahwa pengetahuan keuangan merupakan faktor yang signifikan dalam pengambilan keputusan investasi.

Theory of Reasoned Action (TRA) atau Teori Tindakan Beralasan atau Teori Aksi Beralasan mengatakan bahwa sikap mempengaruhi perilaku melalui suatu proses pengambilan keputusan yang teliti dan beralasan, dan dampaknya terbatas. Secara singkat, praktik atau perilaku menurut Theory of Reasoned Action (TRA) dipengaruhi oleh niat, sedangkan niat dipengaruhi oleh sikap dan norma subyektif. Hal ini menunjukkan bahwa niat berperilaku dapat menunjukkan perilaku yang akan dilakukan oleh seseorang.

Hal tersebut juga berarti bahwa seorang yang memiliki minat berinvestasi maka kemungkinan besar dia akan melakukan tindakan yang dapat mencapai keinginan mereka untuk berinvestasi, seperti mengikuti pelatihan dan seminar tentang investasi, menerima dengan baik penawaran investasi, dan pada akhirya melakukan investasi. Seseorang yang memiliki pengetahuan keuangan lebih tinggi perilaku keuangannya lebih baik dan bertanggung jawab. Pengetahuan atau edukasi mengenai investasi mutlak dibutuhkan bagi seorang calon investor sebelum terjun ke dunia pasar modal atau bisnis. Pengetahuan yang memadai ini akan membentuk kecakapan sesorang dalam menciptakan nilai dan keuntungan dan juga mampu mengelola sebuah resiko yang ada baik kecil maupun besar sehingga mengurangi dampak kerugian yang akan dialami.

Pengaruh Kompatibilitas Terhadap Minat Berinvestasi

Hasil penelitian ini menunjukkan bahwa variabel kompatibilitas memengaruhi minat berinvestasi mahasiswa. Hal ini sesuai dengan penelitian Chakravarty \& Dubinsky (2005) bahwa kompatibilitas berpengaruh terhadap minat berinvestasi.

Teori heuristik didefinisikan sebagai strategi pengambilan keputusan yang cepat dan kadang tidak menggunakan banyak informasi karena pengambil keputusan menganggap sebagai suatu kebiasaan. Niat dari seorang investor 
akan dipengaruhi oleh kebiasaannya dalam berinvestasi karena investor menganggap bahwa investasi di pasar modal sesuai dengan hidupnya.

Kompatibilitas dianggap sebagai kebiasaan atau gaya hidup sehingga tidak memerlukan usaha dalam melakukan investasi. Moore \& Bensabat (1991) mengemukakan bahwa kompatibilitas berpengaruh positif dengan niat seseorang dalam berinvestasi saham. Seseorang yang sudah banyak mendengar tentang berinvestasi saham maka dengan sendirinya akan mengubah cara berfikirnya untuk berinvestasi saham. Tornatzky \& Klein (1982) melakukan meta-analisa atas 100 makalah riset inovasi dan menyimpulkan bahwa keunggulan, kompatibilitas dan kompleksitas merupakan 3 faktor besar yang menentukan keputusan dibalik perilaku investor. Selain itu, kompatibilitas

sangat berpengaruh terhadap keinginan investor dalam beberapa bidang lainnya.

\section{KESIMPULAN DAN SARAN}

Berdasarkan hasil penelitian ini mampu membuktikan bahwa variabel pengetahuan dan kompatibilitas dapat mempengaruhi minat berinvestasi di pasar modal pada mahasiswa. Pengaruh pengetahuan dan kompatibilitas terhadap minat investasi di pasar modal berpengaruh positif signifikan. Hasil penelitian ini menunjukkan bahwa materi yang diberikan pada mata kuliah Keuangan Bisnis dan Pasar Modal dan Manajemen Resiko mampu memberikan pemahaman mendasar terkait dengan berinvestasi di pasar modal. Dengan adanya pojok bursa di Politeknik Negeri Batam juga mampu mempermudah mahasiswa dalam berinvestasi dan mampu meningkatkan minat mahasiswa dalam berinvestasi.

Saran yang dapat penulis sampaikan untuk penelitian yang akan datang ialah, penelitian selanjutnya diharapkan dapat melakukan tanya jawab secara langsung dengan responden atau data wawancara sebagai instrumen penelitiannya, agar penelitian lebih lengkap dan pengaruh bias tidak dapat diukur.

\section{DAFTAR PUSTAKA}

Ajzen, I. (1985). From intentions of action: A theory of planned behaviour. Retrieved from In J.Kuhl \& J. Beckman: http:/www.utwente.nl/cw/theorieenoverzich t/TheoryClusters/HealthCommunication/the ory_planned_behavior/

Chakravarty, S., \& Dubinsky, A. (2005). Individual investors reactions todecimalization: Innovation diffusion in financial markets. Journal of Economic Psychology, 89-103.

Evans, A. (2006). Subject perceptions of confidence and predictive validity in financial cues. Journal of behavioral Finance, 12-28.

Ghozali, H. I. (2013). Aplikasi Analisis Multivariate Dengan Program IBM SPSS21. Semarang: Badan Penerbit Universitas Diponegoro.

Halim, A. (2005). Analisis Investasi. In A. Halim, Analisis Investasi (p. 4). Jakarta: Salemba Empat.

Investor Daily Indonesia. (2011, February 24). Retrieved from Investort Daily

Indonesia Web Site:
http://id.beritasatu.com/home/memberipencerahan-kepada-investor-saham/6357

Jogiyanto, H. (2010). Teori Portofolio dan Analisis Investasi. Yogyakarta: BPFE.

Kahneman, D., \& Tversky, A. (1974). Judgement under uncertainty heuristics and Science,. 185, 1124-1131.

Merawati, L. K. (2015). Kemampuan Pelatihan Pasar Modal Memoderasi Pengaruh Pengetahuan Investasi Dan Penghasilan Pada Minat Berinvestasi Mahasiswa. Jurnal Ilmiah Akuntasi dan Bisnis, Vol. 10 . No. 2, 105-118.

Moore, G. C., \& Bensabat, I. (1991). Development of an instrument to measurethe perceptions of adopting an information technology innovation. Information Systems Research, 2., 192-222.

Njuguna, P. K. (2017). Determinants Of Investment Intention Of Individual Retail Stock Market Investors On The Nairobi Securities Exchangen In Kenya. Kenya: Jomo Kenyatta University Of Agriculture And Technology. 
Pajar, R. C. (2017). Pengaruh Motivasi Investasi Dan Pengetahuan Investasi Terhadap Minat Investasi Dipasar Modal Pada Mahasiswa FE UNY. Jurnal Profita Edisi 1, 2-6.

Robb, C. A. (2011). Financial Knowledge and credit card behaviour of college students. Spinger Science and Business Media, 690698.

Rogers, E. M. (1995). Diffusion of Innovations, (4th ed). New York: The Free Press.

Tornatzky, L. G., \& Klein, K. J. (1982). Innovation characteristics and innovation adoption-implementation: a meta-analysis of findings. IEEE Transactions on Engineering Managemen, 28-45.

Waweru , M., Munyoki, E., \& Uliana , E. (2008). The effects of behavioral factors in investment decision-making: a survey of institutional investors operating at the Nairobi Stock Exchange. International Journal of Business and Emerging Markets, 24-42. 